\title{
Lived Experiences, Academic Performance, and Aspirations of a Muslim Learner in a Public High School
}

\author{
Jennilee T. Abrenica
}

Don Ramon E. Costales Memorial National High School

\begin{abstract}
-
This study was conducted to narrate the experiences, academic performance, and aspirations of a Muslim learner in a public high school. The findings of the study served as the basis for understanding the learning situation and performance of the learner. Specifically, this study sought to: describe the living condition of the Muslim learner in terms of family income and size and how these affected her academic performance; discuss the aspirations, experiences, and challenges of the Muslim learner in a public high school; and describe the academic performance of the Muslim learner during her stay in a public high school. The researcher employed the qualitative research design, particularly the case study method of research. The researcher, later on, came up with themes to describe the experiences and performance of the Muslim learner and a recommendation for future research was also made by the researcher. These were the themes presented in this paper: (1) Experiences in a public high school. (2) Quality of education. (3) Family support. (4) Academic performance. (5) Dreams and aspirations. It can be noted that the respondent had positive experiences in her stay in a public high school. She did not feel any discrimination and untoward incident of her being a Muslim. However, she pointed that she would have wanted to have Muslim teachers or included in the curriculum will be lessons specifically for them, as specified in Madrasah education. She had struggled a lot, though, in her academic performance, because of difficult situations she had experienced.
\end{abstract}

Keywords - Muslim learner, experiences, perceptions, academic performance, family support, education

\section{Introduction}

"Education is the most powerful weapon which you can use to change the world. It is the great engine of personal development. It is through education that the daughter of a peasant can become a doctor, that the son of a mine worker can become the head of the mine; that a child of farm workers can become the president of a great nation. It is what we make out of what we have, not what we are given, that separates one person from another"

As people, especially our parents, always put it, education is one of the best treasures that one person can have in his life. It gives a person knowledge, skills, attitude, values, and ethics, which are all important in this life, for his future and the future of the next generation. It is, if not always, a measure of success for most people, especially for parents.

It is now then important to be sent to a school that will cater and satisfy the needs of the learners for them to become successful in life. Often than not, parents get to choose where to send their children in their elementary, secondary, and tertiary years. They look for schools that will be of great service and great venue of learning, of honing their children's talents and skills, and of molding them to become better, if not the best, individuals.

Throughout the country, all public schools practice inclusive education, wherein they accommodate all types of learners. They do not only accommodate just one type of learner but they accept all students even with different walks of life, beliefs, and religions. Even non-Muslim public schools accept Muslim students and also Muslim teachers. 
It is no longer new to us to see students of other religions enrolling in a school with most students who are of different religions from them. However, are there any significant and different experiences of a Muslim learner who is enrolled in a non-Muslim secondary school or a public high school? Has there been any effect of this to them being able to practice their own religion or is there a strong support system for them in their studies?

In this paper, I have explored the experiences, perceptions, academic performance and even challenges encountered by a Muslim learner enrolled in a public high school. There were similarities and differences noted from previous researches and studies and were all presented in this paper.

\section{Literature Review}

Numerous diverse research and prior literature had looked into Muslim learners' experiences, views, and performance in various settings, locales, and academic institutions. Most of them concluded that schools should be able to cater to the needs of their culturally and religiously diverse populations in order to provide better, more equitable, and more fulfilling school experiences for religiously and culturally diverse children, particularly Muslim students. (Amjad, 2018; Meymand, 2018; Naparan \& Balimbingan, 2020).

In the study entitled Muslim students' experiences and perspectives on current teaching practices in Canadian schools, conducted by Amjad (2018) it was found out that relationship with peers was the most common theme that emerged from the data, followed by teachers and their attitudes towards Muslim immigrant children. Almost all of the researcher's participants appreciated how, in their elementary grades, when they newly arrived in their schools, teachers were nice to them and tried to help them adjust to their school environments. Some of the participants who were not used to this kind of attitude from their teachers back home even felt quite overwhelmed by their teachers' behavior. Unfortunately, things got worse in high school when teachers started teaching about current global issues - specifically 9/11.

In another study by Haj-Yehia \& Erez (2018), it says that students who learn or study in an atmosphere where they are the minority have their identities questioned. Like an Arab Muslim student who was assigned to study in Germany as part of a student exchange program. The student observed that people were always looking at her as she was wearing a hijab. So, she responded to them, showing that she is a peaceful Muslim girl.

In the Philippines, a study conducted by Naparan and Balimbingan (2020), entitled Challenges and coping mechanisms of Muslim students in a Catholic higher education institution, noted that one of the themes that emerged in their study was quality education. There were thirteen significant statements pertaining to the quality of education. This topic includes particular reasons such as creating excellent graduates who are internationally competitive, the school's learning, assisting students in achieving excellence, and qualified teachers. Students will enroll in a higher education institution if they feel they will receive a high-quality education in return. Muslim students in this research believe in the quality of education that the institution can provide for them.

In the same study, other themes that came out were teachers who are not considering the views of others, very early activities, disagreement with parents, language barrier, and adjustment. According to them, there are also few teachers who were not open-minded and thus, they do not consider the opinions and views of others especially their students. As the school sometimes had activities that were held at dawn, the participants also had difficulty, especially in attending these activities. There were also some parents of the research participants who do not like that their children would be sent to a Catholic school, yet their children want to study in those schools. Thus, this resulted to one of the challenges that these students experienced.

With all of this information, the researcher designed this study to learn more about the case of a Muslim student and see if the student had similar experiences to those investigated by other researchers.

\section{Objectives}

This study was conducted to narrate the experiences, academic performance, and aspirations of a Muslim learner in a public high school. The respondent of the study is a Grade 12 Muslim senior high school student. The findings of the study will serve as the basis for understanding the learning situation and performance of a Muslim learner.

Specifically, this study sought to: 
1. Describe the living condition of the Muslim learner in terms of family income and size and how does this affect her academic performance;

2. Discuss the aspirations, experiences, and challenges of the Muslim learner in a public high school; and

3. Describe the academic performance of the Muslim learner during her stay in a public high school.

\section{Methods}

This research study used the qualitative research design, particularly the case study method of research. The case study approach allows in-depth, multi-faceted explorations of complex issues in their real-life settings. This method is particularly beneficial when it is necessary to gain a thorough understanding of a topic, event, or phenomenon of interest in its natural setting. (Crowe, et. al., 2011) A case study is a detailed study of a specific subject, such as a person, group, place, event, organization, or phenomenon, in this case, I specifically chose a person, a Muslim learner to be specific, to be my case. Case studies are commonly used in social, educational, clinical, and business research. (McCombes, 2019)

After developing the problem statement and research questions, I selected the case to be studied. The next step was collecting the data needed for the case study. There are many different research methods that we can use to collect data on our subject. Case studies tend to focus on qualitative data using methods such as interviews, observations, and analysis of primary and secondary sources (e.g., newspaper articles, photographs, official records). In this case, I conducted a face-to-face interview with the subject (following and observing all necessary health and safety protocols), observations of gestures and facial reactions, and I also looked into official records like her school records, specifically her report card.

After collecting, transcribing, and analyzing the data, all relevant aspects were brought together to come up with a clear picture of the subject.

\section{Results And Discussion}

This part of the paper presents the results of the study through the themes that emerged after the data were analyzed. It will specifically narrate the lived experiences of a Muslim learner in a public high school. As a case study, the goal was to report and come up with a thorough understanding of the experiences, aspirations, and academic performance of the subject. This is also followed by a discussion of the themes. The following themes have been seen in the data analysis and will be the flow of the discussion. (1) Experiences in a public high school. (2) Quality of education. (3) Family support. (4) Academic performance. (5) Dreams and aspirations The major research question for this study was "How do you describe your experiences as a Muslim learner in a public high school and a non-Muslim school, at that?". The experiences shared, aspirations mentioned, and challenges experienced were analyzed. The academic performance of the subject was also analyzed as she shared how she performed during her high school.

All relevant and significant aspects of the interview were brought together, analyzed, and came up with a narration that detailed the lived experiences, aspirations, and academic performance of the subject. The topics are outlined below for a better understanding and clearer picture of the case study.

\section{Experiences in a public high school}

As a Muslim learner, she has had fair experiences in school. She shared that she had happy and meaningful experiences in a public school, both during her Junior High School and Senior High School. She would recall that despite her religious affiliation, she did not feel any discrimination. All of her classmates and teachers were very warm and accommodating. During Grade 11, she also had a cousin who studied in the same school, and they were enrolled in the same class, so there was also someone whom she could talk with about anything.

In a study conducted by Ahmed (2016), Exploring the Experiences of Muslim Students in an Urban Ontario Public School, the findings appear to support the idea that Muslim pupils are supported and accepted in the school in many ways. Multiple support mechanisms, both explicit and tacit, are in place to help Muslim kids feel at ease at school. They get along well with their professors and authorities. In this case, the respondent shared the same finding that she was also accepted in many ways despite her religious affiliation.

But according to her, it would have been great if she had an "asatidz" to talk with in the school. 
"Asatidz" is the plural form of the Arabic word "ustadz", a term that refers to a male teacher and "ustadzah", a term that refers to a female teacher. This is the general Arabic term for teachers historically or traditionally used in most Filipino Muslim communities (DepEd Order No. 41, s. 2017). According to the respondent, if there were asatidz in public schools, it would be great for them, Muslim learners, to have someone they can communicate with about their performance, concerns, and the like.

In the same paper by Ahmed (2016), one of the challenges faced by Muslim students is curriculum-related challenges. Muslim students want to see themselves in the curriculum. By this, the respondent shared that it would have been great if there is also a part wherein everyone is educated about Muslim culture and tradition, maybe during homeroom guidance program. Another is the presence of asatidz in the school. To at least have one Muslim teacher that they can go to if they are facing issues related to their being a Muslim.

The respondent recalled that there were just some instances when they, she and her cousin, talked in their dialect, and other students will become suspicious that they were talking about them. In this case, she seeks to be understood that there are times that they feel more comfortable also when they speak their dialect. However, she said that when they explained that they are not talking about anyone, the other students also understood them. She said that it is just the same when most of the students will speak in Ilocano, they also feel the same, but nevertheless, the respect for one another is always there. After all, throughout the more than 7,000 island archipelagos, Filipinos speak nearly 90 languages and dialects. The three major dialects are Ilocano (northern Luzon, also the dialect spoken most commonly by Filipinos in Hawaii and on the U.S. mainland); Tagalog (central and southern Luzon); and Cebuano (southern islands) (BYU, 1986).

Both men and women are required to dress modestly in Islam. Muslim women, on the other hand, have unique clothing that they may choose to wear to protect their modesty. To protect their modesty, many Muslim women wear a hijab or veil. This is not something that all Muslim women choose to do. (BBC, 2021) The respondent said that she did not feel discriminated even with the way she had to dress in school. Though she also wears the school uniform, she always wears her hijab. A hijab is the name of the headscarf worn by Muslim women. They come in a variety of styles and colors. (BBC, 2021) According to the respondent, she wears her jihab because it is what her heart wants. "Wearing a jihab should come from the heart", she said.

\section{Quality of Education}

In the scope of education, Islamic education is very important for school students, even small children, before entering the world of school, also need to be given Islamic education so that when children enter the world of education, they will get used to it and they only need to add and implement it in everyday life (Hassan, 2019). According to the respondent, it is all right to be in a non-Muslim institution as long as they have been taught early on in their lives regarding their religion. However, if she were enrolled in a Muslim institution, she would have four days devoted to academics and three days for Arabic Language and Islamic Values.

DepEd Order No. 41, series of 2017 tells us about the Policy Guidelines on Madrasah Education in the K to 12 Basic Education Program. The program aims to provide Muslim learners with appropriate and relevant educational opportunities while recognizing their cultural contexts and unique purposes for participating in the program offerings. It also aims to integrate content and competencies which are relevant and of interest to Muslim learners. In this program, there should be an Arabic Language and Islamic Values Education (ALIVE) which is a program implemented in public schools which aims to provide additional subjects on Arabic Language and Islamic Values in the regular basic education curriculum.

I implored the respondent if she had ever experienced receiving this kind of program or any program related to her religion, but she said that she did not experience it during her elementary, Junior High School, and Senior High School. She said that it would have been great if this policy was well-implemented in public schools because it will help her a great deal and her co-Muslim learners.

According to her, it is important to graduate and have a diploma in Senior High School because it is very important for them, Muslim learners, if they want to somehow enter into other Muslim countries or higher Muslim institutions. That is why, despite all the challenges she has experienced as a student, she pursues her dream of graduating from this public institution. 
When asked about the quality of education that she gets from a public high school, she said that in terms of academic subjects, she thinks highly of the teachers and the subjects that they taught and are teaching. While they are too technical, she believes that these are all essential subjects for her and her future. But as mentioned earlier, she said that it would have been great if she had an "asatidz" to talk with in the school.

\section{Family Support}

Thirty years of research confirms that family involvement is a powerful influence on children's achievement in school (Eagle, 1989; Henderson \& Berla, 1994; U.S. Department of Education, 1994; Ziegler, 1987). Children who have their families involved in their education earn higher grades and test scores, attend school more regularly, complete more homework, demonstrate more positive attitudes and behaviors, graduate from high school at higher rates, and are more likely to enroll in higher education than students who do not have their families involved in their children's education. As a result, boosting parental participation in their children's education is a critical objective for schools, particularly those serving low-income and other at-risk students.

The respondent is the third among eight children. They were all born and nurtured in this community, in the Province of Pangasinan, but they do practice their belief and religion since birth. According to her, having been born in a large family, they had to make ends meet. She started to work when she was in Grade 7 and stopped schooling because of the situation. Until now, she works in a cellphone repair and supplies shop owned by their relative to help her family and herself.

According to her, it is very hard to study and work at the same time. But given their situation and it is also expected from them to know more about business as their family is looking into those Muslim children who are inclined to business. Business is significant in Islam. Everywhere in Quran mention about business. The personality and character of prophet Muhammad were nurtured through business (Atan, et. Al., 2017). It is because of this that they are also working at an early age, but their studies are somehow affected because of their jobs or works.

Recently, she said that she even sent a message to her adviser saying that even her mother does not support her in her studies. So, she wants to stop again in her Senior High School because of family struggles and problems.

"Ma'am, sorry po, pinaasa ko po kayo. Ibagsak niyo na po ako. Wala rin naman silbi pag-aaral ko, ni suporta ng nanay ko wala. Pasensya na po" [Ma'am, I am so sorry that I kept your hopes high that I will return my modules. Just give me failing grades. My schooling has no direction, and even my mother does not support me. I apologize profusely.]

The proof is certain. Students get better grades, score higher on standardized tests, and drop out less often when their parents are involved in their child's education. They also have better attendance records, higher aspirations, and more positive attitudes about school and homework when their parents are involved in their child's education. Furthermore, these favorable effects appear to be especially relevant for children growing up in lowincome, high-stress environments. (Johnson, et.al., 2004, Li \& Qiu, 2018) If children feel the support of their parents or families, they do not have the tendency to drop out or stop schooling. They will feel that they are supported and that they should finish whatever they have started with flying colors.

The respondent also shared that her family's financial situation is hindering her from going and attending school. She lives far from the school, about eight kilometers, by a public utility vehicle and consumes about fifty pesos a day for transportation fees and other allowances. Since they are making ends meet, the expenses in school can be quite burdensome for their family. There were times when she did not attend school because of this. During the pandemic, when supposedly they are just at home, she concentrated on her work, making less time to answer her modules and activity sheets.

She also recalled another experience when she was in Junior High School that they had to be absent from school because all their finances will be spent for her brother, who decided to marry. According to Islamic law, Muslim marriage contracts require specifying a mehr, mahr, mehrieh, or dowry, a monetary payment from the husband to the wife (Bianquis 1996, Carroll, 1986). A dowry in the Muslim faith is a gift, or a promise of a gift, to the wife by the husband. It is negotiated shortly before the couple's marriage and is often in written form. It is often in the form of gold coins, cash, or land. It is not given to the wife at the time of the marriage, but the wife has the right to ask for it at any time during the marriage or upon the dissolution of the marriage 
(Golesorkhi, 2014). Having experienced this, she shared that it may have been a celebration for their family but for her, it is another hardship and struggle because they had to sacrifice their schooling for this matter.

As we were progressing in this paper, she said that she again started to miss her submission of modules and activity sheets, poorly communicated with her teachers, and she again was not given grades by some of her teachers because of incomplete or totally no outputs.

\section{Academic Performance in School}

The respondent shared that she really had difficult times during her high school years because of all the situations and experiences that she had. Because she had to juggle her studies and work and her roles in the household, her academic performance in school ranged from being not able to meet expectations to fairly satisfactory.

She recalled that when she was in Grade 11, she failed in one subject (below 75 or did not meet expectations) during the first quarter of the first semester, and her final grades were almost fairly satisfactory (rating of 7579). During the second semester, her academic performance was worse than her first semester because she failed her five (5) subjects as evident in her School Form 10 (SF10) and School Form 9 (SF9 or report card). It was devastating for her but she cannot do anything about it because, admittedly, she was not able to perform well in school. The respondent recalled that during her Grade 12, first semester she again had struggled a lot just to finish off the semester. Even if the mode of learning is modular printed, she had difficulty coping up because of her work.

The respondent shared that it was difficult to work and study at the same time. Working made her feel tired and stressed, and so most of the time, she neglected her duties in school. She was not able to review lessons before examinations, cannot meet deadlines, and got low scores during assessments.

In the Theory of the Allocation of Time (Becker, 1965), the Zero-Sum Theory suggests that student employment and education are substitutes. It is said that student employment severely limits students' use of time: time spent working displaces time spent on activities that improve academic success, e.g., studying and doing homework (Bozick, 2007; Kalenkoski \& Pabilonia, 2009). As a result of the loss in academic time owing to time spent working, academic performance declines. All of these were evident in the respondent's experience wherein her employment had a detrimental effect on her performance.

Performance in school does not only include academic performance but also attendance to classes. The respondent said that when the mode of learning was face to face, she was most of the time absent from her classes because she needed to work. Even during the modular mode of learning, she barely had time to answer modules.

Her academic performance was also affected because of a lack of family support. As mentioned earlier, she even sent her adviser a message that even her mother does not support her, and she feels sorry to her adviser for having made her expect that she will continue with her schooling.

When her teacher followed up on her modules, she said that she wanted to stop her schooling because she felt that her family does not support her. Families have a tremendous impact on children's learning behaviors and academic accomplishment since they are the children's primary and most significant surroundings. According to Coleman (1966), families may play even more important roles in student's academic achievement than schools and communities. Since then, empirical study on family background and children's achievement has discovered that family socioeconomic status and family support may have a greater impact on children's academic achievements than the impact of schools. (Li and Qiu, 2018; Coleman et al. 1966; Peaker 1971; Sirin 2005; Cheadle 2008).

In reality, not only does the quality of the school have an impact on students' academic accomplishment during compulsory education, but the approaches and abilities of parents' participation in their children's compulsory education also have an impact. Indeed, family involvement is a powerful influence on children's achievement in school (Eagle, 1989; Henderson \& Berla, 1994; Ziegler, 1987). According to the respondent, if only her parents would have been supportive from the beginning, she may have had better grades, better attendance, and better performance in school. 


\section{Aspirations and Dreams}

Despite all the challenges that she encountered, she also aspires and dreams that someday she will have better opportunities in her schooling. According to her, she must finish her high school and get a diploma for her to be able to enter higher institutions. According to her, getting a diploma despite all the challenges will be a great accomplishment for her. In the Private Christian Schools page (2018), if getting a college degree is necessary for one's ideal job, earning a high school diploma can significantly improve the chances of completing that degree. Basically, it will allow you to go to college, which is the respondent's ultimate dream. According to her, she wants to pursue her tertiary education in Baguio City or in Manila or even in other countries, if only the situation will allow her to. A high school graduation will open doors and more chances in life than just a job. You're more likely to be above the poverty level, allowing you to apply for home, auto, or education loans. With a high school graduation, you'll be more likely to reside in a low-crime area and avoid running afoul of the law.

She also dreams that one day in the Philippines, in public schools, there will be a greater opportunity for Muslim learners and also the full implementation of DepEd Order No. 41 or Madrasah education. Though she did not feel any discrimination towards her during her high school days, it would be great for other students to be aware and educated about Muslim culture and beliefs, as well.

\section{Conclusion And Recommendations}

The experiences of a Muslim learner were identified and presented in this paper. It can be noted that the respondent had positive experiences in her stay in a public high school. However, we should still look into other cases or other Muslim students as they may have had different experiences. Muslim experiences vary depending on the concentration of Muslim populations in particular states, cities, and regions. In the study of Jilani (2015), it was noted that the experiences of high school students differed depending on the Muslim student population of the school they attended. Therefore, students may experience favorable conditions in schools based on established precedents and the school being accustomed to having Muslim students.

In the case of the respondent, she did not feel any discrimination and untoward incident of her being a Muslim. However, what she pointed was that she would have wanted to have Muslim teachers or included in the curriculum will be lessons specifically for them, as specified in Madrasah education. This is one of the recommendations of this study that maybe one day, the governing boards and policies will look into this concern. It may not only be the case for her but for other Muslim learners, as well.

The value of student experiences, feelings, and narratives adds layers of complexity to understanding that other types of studies and research can't match. Several research studies on Muslims have yielded useful results due to the large amounts of data and quantitative methodologies used. In addition, a number of studies have concentrated on Muslim post-secondary education. However, there has been a few, if any, qualitative research on how these events affect Muslim adolescent identity.

All stakeholders benefit from knowing and understanding the situation of Muslim learners. Both at home and at school, parents, school officials, teachers, peers, and community members have a crucial part in molding the beliefs and personalities of adolescents. The support of parents is one of the most important things for a student to become motivated in school; thus, he or she can perform well and will achieve better outputs and performance that may affect her future. Therefore, this paper should reach parents so that they can give their support to their children.

\section{Areas for future research}

The case study of a Muslim learner in high school provides a rich discussion regarding how accommodating and inclusive public-school environment for them and the gap that minimal concerns were raised by the subject during her stay in a public high school. A possible area to build further on this research is to study public schools where there are more Muslim students and Muslim teachers as well if the experiences will still be the same or would be different. Since this is just focused on one learner, it does not represent most of the Muslim community in terms of their experiences in public school. Another possible area of research is to study also the experiences of Muslim teachers in public schools. It would also be interesting to see researchers examine and study if these Muslim learners have difficulties and challenges in terms of family support. A comparison of 
performance between Muslim learners with supportive parents and good economic position and those with unsupportive parents and poor living conditions can also be made.

\section{Conflict Of Interest}

The researcher declare that the research was conducted in the absence of any commercial or financial relationships that could be construed as a potential conflict of interest.

\section{Acknowledgement}

The researcher would like to thank and acknowledge the respondent for allowing her to interview and conduct this study. The researcher thanks her for giving her confidence in the author and for sharing most, if not all, her experiences in a public high school.

The researcher would like to recognize and acknowledge Dr. Christopher J. Cocal for his guidance and support in this endeavor. His love and passion for research and his insightful discussions kept the author going and helped a lot to come up with this piece of work.

To the author's family, every single accomplishment is dedicated to you!

Above all, to God be the highest honors and praises!

\section{References}

\section{Published Journals}

1. Ahmed, Asma. (2016). Exploring the Experiences of Muslim Students in an Urban Ontario Public School.

2. Amjad, Afshan. (2018). Muslim students' experiences and perspectives on current teaching practices in Canadian schools. Institute for Educational Development, Aga Khan University, Pakistan.

3. Becker, G. S. (1965). A theory of the allocation of time. The Economic Journal 75.

4. Bozick, Robert. (2007). Making it through the first year of college: The role of students' economic resources, employment, and living arrangements. Sociology of Education.

5. Cheadle, Jacob E. (2008). Educational investment, family context, and children's math and reading growth from kindergarten through the third grade. Sociology of Education.

6. Coleman, J.S., E.Q. Campbell, and C.J. Hobson. (1966). Equality of educational opportunity. Washington: National Center for Educational Statistics (DHEW/OE).

7. Coleman, James S. (1988). Social capital in the creation of human capital. American Journal of Sociology.

8. Eagle, Eva. (1989). Socioeconomic status, family structure, and parental involvement: The correlates of achievement. Paper presented at the annual meeting of the American Educational Research Association, San Francisco.

9. Jilani, Iram Jamil Shaikh. (2015). Muslim American Identity under Siege: Muslim Students' perspective of American High Schools. Northeastern University Boston, Massachusetts.

10. Kalenkoski, C. M., \& Pabilonia, S. W. (2009). Does working while in high school reduce US study time? Social Indicators Research.

11. Li, Z. \& Qiu, Z. (2018). How does family background affect children's educational achievement? Evidence from Contemporary China. The Journal of Chinese Sociology.

12. Naparan, G. B. \& Balimbingan, N. A. (2020). Challenges and coping mechanisms of Muslim students in a Catholic higher education institution. Saint Columban College, Pagadian City, Philippines.

13. Peaker, Gilbert F. (1971). The Plowden children four years later. Slough: National Foundation for Educational Research in England and Wales.

14. Sirin, Selcuk R. (2005). Socioeconomic status and academic achievement: a meta-analytic review of research. Review of Educational Research.

15. South Africa: Minister Hlengiwe Mkhize. (2018). 2018 Higher Education Registration Process." MENA Report, Albawaba (London) Ltd. 
16. Ziegler, S. (1987). The effects of parent involvement on children's achievement. The significance of home/school links. Toronto, Canada: Toronto Board of Education.

\section{Online References}

17. Archived: Family Involvement in Children's Education .... Retrieved from: https://www2.ed.gov/pubs/FamInvolve/execsumm.html. Date Retrieved: July 1, 2021.

18. BBC. (2021). Muslim identity and ummah. Retrieved from https://www.bbc.co.uk/bitesize/guides/zpyvxfr/revision/6 Date Retrieved: July 6, 2021

19. BYU. (1986). Issues of Language. Retrieved from https://www.livinginthephilippines.com/culture-andpeople/philippine-culture/406-issues-of-language. Date Retrieved: July 6, 2021.

20. Crowe, S. et. al. (2011). The case study approach. BMC Med Res Methodol Journal. Retrieved from https://www.ncbi.nlm.nih.gov/pmc/articles/PMC3141799/ Date Retrieved: July 1, 2021.

21. DepEd Order No. 41, s. 2017. Retrieved from https://www.deped.gov.ph/2017/08/11/do-41-s-2017policy-guidelines-on-madrasah-education-in-the-k-to-12-basic-education-program/. Date Retrieved: July $1,2021$.

22. Educators, Inc. Private Christian Schools. (2018). Why is graduating high school so important? Retrieved from https://www.educatorsinc.org/post/why-is-graduating-high-school-so-important. Date Retrieved: July 1, 2021.

23. Emery, Debbie. (2014). 5 Key Indicators of School Performance Retrieved from https://flippengroup.com/5-key-indicators-school-performance-2/. Date Retrieved: July 3, 2021.

24. Golesorkhi, Reza. (2014). Dowries in the Modern Age: What Happens to an Islamic Mahr, Mehrieh, Mehr, or Dowry, During a Maryland Divorce: Part 1. Retrieved from https://www.jgllaw.com/blog/dowries-modern-age-what-happens-islamic-mahr-mehrieh-mehr-ordowry-during-maryland-divorce. Date Retrieved: July 3, 2021

25. Haj-Yehia, K., \& Erez, M. (2018). The impact of the ERASMUS program on cultural identity: A case study of an Arab Muslim female student from Israel. Women's Studies International Forum, 70, $32-38$. Retrieved from https://doi.org/10.1016/j.wsif.2018.08.001. Date Retrieved: July 1, 2021

26. Henderson, A. T. \& Berla, N., Ed. (1994) A New Generation of Evidence: The Family is Critical to Student Achievement. ERIC. Retrieved from https://eric.ed.gov/?id=ED375968. Date Retrieved: July 1, 2021.

27. How Nelson Mandela created the conditions for success. Retrieved from https://blog.cambridgeinternational.org/nelson-mandela/. Date Retrieved: July 3, 2021.

28. How to Do a Case Study | Examples and Methods. Retrieved from https://www.scribbr.com/methodology/case-study/. Date Retrieved: July 3, 2021.

29. Islamic Education, Important for Students. Retrieved from https://thriveglobal.com/stories/islamiceducation-and-its-importance-for-students/. Date Retrieved: July 1, 2021.

30. McCombes, Shona. (2019). How to do a case study. Retrieved from https://www.scribbr.com/methodology/case-study/. Date Retrieved: July 3, 2021.

31. Muslim Dress Notes. Retrieved from https://www.hrc.co.nz/files/3014/2387/9042/12-Jan-2007_10-0007_Muslim_Dress_Notes.pdf. Date Retrieved: July 3, 2021. 